\title{
Comparative RFLP Profiles among Representative Strains of Japanese Races of Xanthomonas oryzae pv. oryzae Using the Repetitive DNA Probe pJEL101
}

\author{
Hisatoshi KAKU*, Kazuyuki HirayaE*,**, Hirokazu OchiaI*, Satoko Kanematsu*,***, \\ Takahito NoDA ${ }^{\dagger}$, Kenichi TsuchIYA* and Tadaaki HiBI*,+†
}

\begin{abstract}
Key words : Xanthomonas oryzae pv. oryzae, bacterial leaf blight, restriction fragment length polymorphism (RFLP), genetic diversity.
\end{abstract}

Bacterial leaf blight caused by Xanthomonas oryzae pv. oryzae is one of the most destructive diseases of rice in Asia. Use of varietal resistance has been an effective and economical control method against the disease. However, the results are not always successful, because of the existence of many races of the pathogen. Therefore, information on the race distribution is required to select rice cultivars resistant to the disease. Race differentiation is laborious and time-consuming work due to growing differential varieties, inoculation and scoring. Therefore, development of new methods for the purpose has been expected.

Restriction fragment length polymorphism (RFLP) analysis has been used to classify bacterial genera, species, and pathovars ${ }^{3}$. Leach et al. ${ }^{5)}$ detected highly repetitive DNA sequences in the genome of $X$. $O$. pv. oryzae. They indicated that one sequence designated as pJEL101 can be used as a probe for pathovar and strain identification as well as for population analysis ${ }^{5,6)}$.

In Japan, a differential system distinct from that of IRRI was established. According to the system, strains of $X$. o. pv. oryzae from Japan and Indonesia have been classified into races I to VII on the basis of their pathogenicity to the differential varieties ${ }^{1,8,9,11)}$. The representative strains of Japanese races of $X$. o. pv. oryzae have been used as reference strains not only in rice breeding program but in various aspects of the research in other countries as well as in Japan ${ }^{1,5,9,11)}$.

In this study, therefore, the representative strains of Japanese races of $X$. $o$. pv. oryzae were compared by RFLP using the probe pJEL101 to set up the standard for genetic diversity analysis. It was also studied here whether the strains representative of each race are distinguishable each other and from Indonesian strains by RFLP using the same probe towards the application to race differentiation.

The strains of $X . o$. pv. oryzae used in this study were T7174 (race I) ; T7147 (race II) ; T7133 (race III) ; H75373 and Xo-7435 (race IV) ; H75304 and Xo-7306 (race V) and H8584 (race VII). Of these strains, Xo-7435 and Xo-7306 were obtained in Indonesia by Yamamoto et al. ${ }^{11)}$, and have been also used as representatives of races IV and $\mathrm{V}$, respectively. Source and available information concerning the representative strains is presented in Table 1. In addition to the representatives of the races, certain strains from races I, II and III were analyzed for RFLP pattern to compare the genetic diversity within a race.

The bacterial strains were grown in liquid medium containing $10 \mathrm{~g}$ of peptone, $5 \mathrm{~g}$ of sucrose and $1 \mathrm{~g}$ of L-glutamic acid per liter for $16 \mathrm{hr}$ at $28^{\circ} \mathrm{C}$ on a rotary shaker. The bacterial cells were harvested and washed with STE buffer. Genomic DNA was extracted by the modified procedure of Wilson ${ }^{9}$. The bacterial DNA (approximately $1 \mu \mathrm{g}$ ) was digested to completion with Eco RI, Bam HI, ClaI or HindIII at $37^{\circ} \mathrm{C}$ for $6 \mathrm{hr}$. The DNA fragments were separated by electrophoresis in $0.8 \%$ agarose gels immersed in Tris-borate buffer. Transfer of the DNA fragments from agarose gel onto nylon membranes, and Southern hybridization were done as described by the manufacturer of the Hybond- $\mathrm{N}$ membrane (Amersham Japan Co. Ltd.). The probe pJEL1015), a pUC18 plasmid containing a $2.4 \mathrm{~kb}$ EcoRIHindIII fragment derived from PXO86 of Philippine race 2 , was labeled with photobiotin ${ }^{7}$. Blots were prehybridized at $42^{\circ} \mathrm{C}$ for $2 \mathrm{hr}$ in a solution composed of $5 \times$ SSPE, $5 \times$ Denhardt's solution, $0.5 \%$ SDS, $50 \%$ formamide

* National Institute of Agrobiological Resources, Tsukuba 305, Japan 農業生物資源研究所

** Present address: Kyushu National Agricultural Experiment Station, Suya, Nishigoushi, Kikuchi-gun, Kumamoto 861-11, Japan 九州農業試験場

*** Present address: Fruit Tree Research Station, Fujimoto, Tsukuba 305, Japan 果樹試験場

† Japan International Research Center for Agricultural Sciences, Owashi, Tsukuba 305, Japan

国際農林水産業研究セ ンター

It Present address: Faculty of Agriculture, The University of Tokyo, Bunkyo-ku, Tokyo 113, Japan 東京大学農学部 
Table 1. Representative strains of each race of Xanthomonas oryzae pv. oryzae in Japanese differential system

\begin{tabular}{lclll}
\hline \hline Strain & Race & \multicolumn{1}{c}{ Location } & Year & Reference \\
\hline T7174 & I & Kyoto Prefecture, Japan & 1971 & Ezuka et al. ${ }^{1)}$ \\
T7147 & II & Gifu Prefecture, Japan & 1971 & Ezuka et al. ${ }^{1)}$ \\
T7133 & III & Mie Prefecture, Japan & 1971 & Ezuka et al. ${ }^{1)}$ \\
H75373 & IV & Okinawa Prefecture, Japan & 1975 & Horino et al. ${ }^{4)}$ \\
H75304 & V & Miyazaki Prefecture, Japan & 1975 & Horino et al. ${ }^{4)}$ \\
H8584 & VII & Miyazaki Prefecture, Japan & 1982 & Noda and Ohuchi ${ }^{8)}$ \\
Xo-7435 & IV & Bali, Indonesia & 1974 & Yamamoto et al..$^{11}$ \\
Xo-7306 & V & Bali, Indonesia & 1973 & Yamamoto et al. ${ }^{11}$ \\
\hline
\end{tabular}

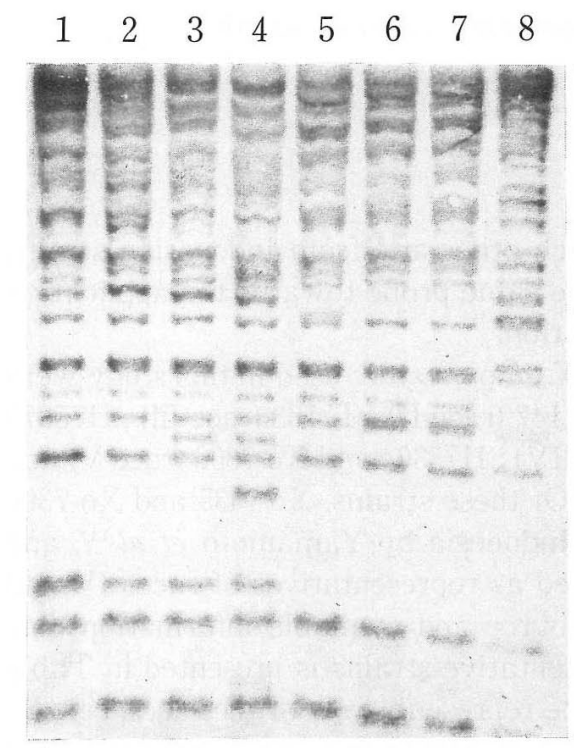

(A)

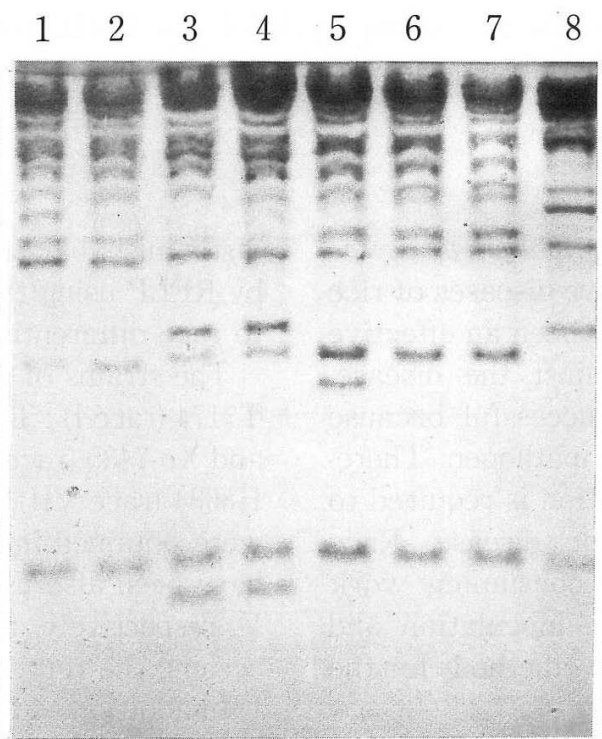

(B)

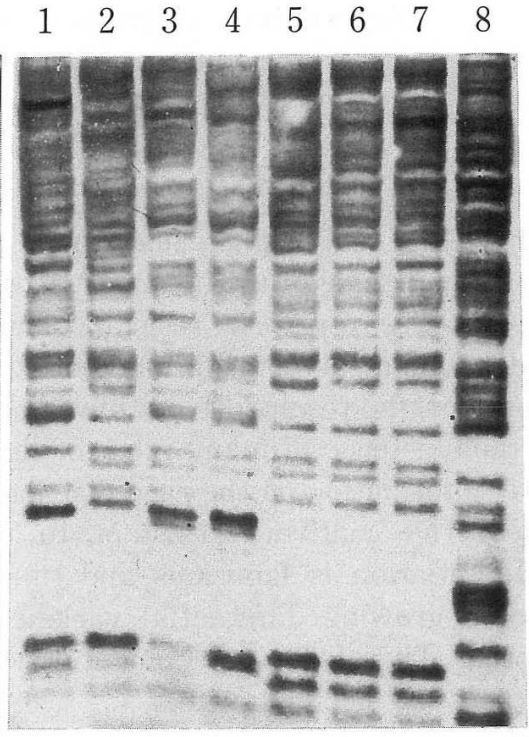

(C)

Fig. 1. Southern blot analysis of total DNA from the representatives of each race of Xanthomonas oryzae pv. oryzae from Japan and Indonesia. The probe was photobiotin-labeled pJEL101. Genomic DNA was digested with EcoRI (A), HindIII (B) and ClaI (C). Lane 1, T7174 from Japan (race I) ; lane 2, T7147 from Japan (race II) ; lane 3, T7133 from Japan (race III); lanes 4 and 5, H75373 and Xo-7435, from Japan and Indonesia, respectively (race IV); lanes 6 and 7, H75304 and Xo-7306, from Japan and Indonesia, respectively (race V), and lane 8, H8584 from Japan (race VII).

and $1 \mathrm{mg} / \mathrm{ml}$ denatured salmon sperm DNA. For hybridization, denatured labeled probe was added directly to the prehybridization solution, and blots were incubated at $42^{\circ} \mathrm{C}$ for $16-18 \mathrm{hr}$. Detection of the blots were carried out using BLUGENE ${ }^{\mathrm{TM}}$ non-radioactive nucleic acid detection kit (BRL, Gaithersburg, Maryland).

The results showed that the representative strains of Japanese races I, II, III, IV, V and VII were distinguished by the RFLP patterns, irrespective of the restriction enzyme used. The RFLP patterns of EcoRI-, HindIII-, and ClaI-digests of total DNA of the representative strains are shown in Fig. $1 \mathrm{~A}, 1 \mathrm{~B}$ and $1 \mathrm{C}$, respectively.

The probe pJEL101 hybridized extensively to digested total genomic DNA from the strains used and numerous bands were detected. The number of the bands was also dependent on the restriction enzyme used.

When EcoRI, most commonly used restriction enzyme, was used as a cutter, T7174 and T7147, repre- sentatives of races I and II, respectively, showed a similar RFLP pattern. However, precise comparison revealed that there was difference between the patterns of the two strains. Other strains were also distinguishable by each specific RFLP pattern, though many common bands were observed (Fig. 1A). The most numerous bands were obtained in the ClaI-digested total DNA (Fig. 1C). When HindIII was used as restriction enzyme, the hybridization was less complex than that observed in DNA digested with Eco RI, and each representative strain could be differentiated clearly and easily by the pattern (Fig. 1B).

Among the strains, H8584, representatives of race VII, showed a very unique pattern, irrespective of the restriction enzymes used. In contrast, T7174 and T7147, representatives of races I and II, respectively, showed a similar RFLP pattern not only in EcoRI digests as mentioned above, but also in other two enzymes digests. However, precise comparison revealed that there was 


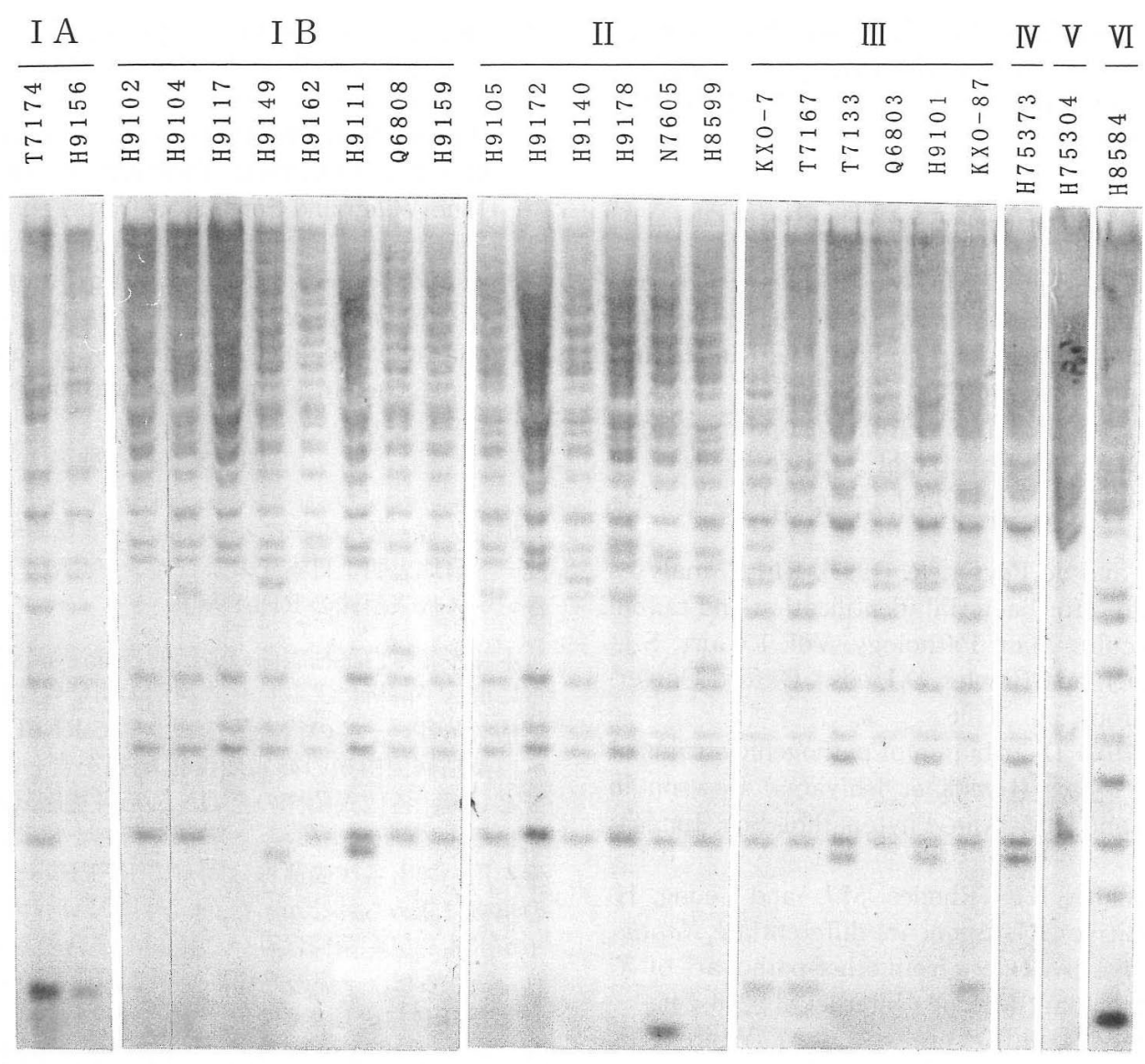

Fig. 2. Southern blot analysis of certain strains belonging to races I (A and B), II and III of $X$. o. pv. oryzae together with representatives of Japanese races IV, V and VII. The probe was photobiotin-labeled pJEL101, and genomic DNA was digested Bam HI.

difference between the patterns of the two strains. The strains $\mathrm{T} 7133$ and $\mathrm{H} 75373$, representative of races III and IV, also revealed the similar RFLP patterns. However, the two strains were differentiated by a specific band or bands. Other strains were also distinguishable by each specific RFLP pattern, though many common bands were observed.

Between Japanese and Indonesian strains, race IV strains H75373 and Xo-7435 from Japan and Indonesia, respectively, showed a different pattern, while the same pattern was observed between the race V strains $\mathrm{H} 75304$ and Xo-7306 from Japan and Indonesia, respectively.

Based on the results obtained here, it appears possible to distinguish the representative strains of Japanese races of $X . o$. pv. oryzae by RFLP patterns. However, when the strains belonging to the same race were analyzed with the same method, RFLP patterns were not always the same.

Figure 2 shows the comparative RFLP patterns of Bam HI-digests from certain strains belonging to race I, II and III, respectively, together with those of the representative strains of other Japanese races. Among the strains belonging to the same race, all of them did not show the same RFLP patterns, and were grouped into subgroups on the basis of their patterns. However, overlapping of the RFLP patterns among the races was not observed except a small number of strains between races $I$ and II.

Ogawa ${ }^{9)}$ tested the pathogenicity of certain strains of $X$. o. pv. oryzae, and he demonstrated that race I and III strains were grouped into two categories $\mathrm{A}$ and $\mathrm{B}$ on the basis of their pathogenicity.

In race I, race IA strain T7174 and H9156 showed a different pattern from other strains belonging to race IB. A similar result was obtained between T7133 (IIIA) and Q6803 (IIIB). Thus, the difference in pathogenicity may coincide with the RFLP patterns.

Further comparison using many strains is necessary to prove that the RFLP analysis can be used to differentiate races of $X$. o. pv. oryzae, though RFLP may be applicable to race differentiation, if the probe is modified or new probe related pathogenicity is developed.

The results obtained here showed that the genetic diversity among the Japanese strains of $X$. o. pv. oryzae can be detected using the probe pJEL101.

Assessment of the genetic diversity of Japanese strains as well as those from South East Asia, i.e. Thailand, Malaysia, India, Nepal, Bungladesh, Myanmar including Indonesia and the Philippines is underway. 
The authors are grateful to Dr. J.E. Leach, Kansas State University, for her kind supply of the DNA probe pJEL101, and to Ilkka Havukkala, STAFF Institute, Tsukuba, for comments on the manuscript.

\section{Literature cited}

1. Ezuka, A. and Horino, O. (1974). Classification of rice varieties and Xanthomonas oryzae strains on the basis of their differential interactions. Bull. Tokai-Kinki Natl. Agric. Exp. Stn. $27: 1-19$.

2. Ezuka, A. and Sakaguchi, S. (1978). Host-parasite relationship in bacterial leaf blight of rice caused by Xanthomonas oryzae. Rev. Plant Protect. Res. 11: 93118.

3. Gabriel, D.W. and de Feyter, R. (1992). RFLP analyses and gene tagging for bacterial identification and taxonomy. In Molecular Plant Pathology, Vol. 1 (Gurr, S.J., McPherson, M.J. and Bowles, D.J. eds.), Oxford University Press, Oxford, pp. 51-66.

4. Horino, O. (1979). Distribution of pathogenic strains of Xanthomonas oryzae (Uyeda et Ishiyama) Dowson in Japan in 1973 and 1975. Ann. Phytopathol. Soc. Jpn. 44: 297-304.

5. Leach, J.E., White, F.F., Rhodes, M.L. and Leung, H. (1990). A repetitive DNA sequence differentiate Xanthomonas campestris pv. oryzae from other pathovars of $X$. campestris. Mol. Plant-Microbe Interact. $3: 238-246$.

6. Leach, J.E., Rhodes, M.L., Vera Cruz, C.M., White, F.F., Mew, T.W. and Leung, H. (1992). Assessment of genetic diversity and population structure of Xanthomonas campestris pv. oryzae with a repetitive DNA element. Appl. Environ. Microbiol. 58 : 2188-2195.

7. McInnes, J.L., Foster, A.C., Skingle, D.C. and Symons, R. H. (1990). Preparation and uses of photobiotin. Methods Enzymol. 184: 588-600.

8. Noda, T. and Ohuchi, A. (1989). A new pathogenic race of Xanthomonas campestris pv. oryzae and inheritance of resistance of differential rice variety, Te-tep to it. Ann. Phytopathol. Soc. Jpn. 55 : 201-207.
9. Ogawa, T. (1983). Pathogenic specialization in bacterial groups I and III of Xanthomonas campestris pv. oryzae. Ann. Phytopathol. Soc. Jpn. 49 : 69-72.

10. Wilson, K. (1990). Preparation of genomic DNA from bacteria. In Current Protocols in Molecular Biology, John Wiley and Sons, New York, pp. 2. 4. 1.-2. 4. 5.

11. Yamamoto, T., Hifni, H.R., Machmud, M., Nishizawa, T. and Tantera, D.M. (1977). Variation in pathogenicity of Xanthomonas oryzae (Dyeda et Ishiyama) Dowson and resistance of rice varieties to the pathogen. Contr. Centr. Res. Inst. Agric. Bogor (Indonesia) 28: 1-22.

\section{和 文 摘 要}

加来久敏 $\cdot$ 平八重一之 $\cdot$ 落合弘和・兼松聡子 $\cdot$ 野田孝人 $\cdot$ 土屋 健一・日比忠明：日本産およびインドネシア産イネ白葉枯病菌 各レース代表菌株の RFLP 解析

本邦産イネ白葉枯病菌の遺伝的多様性解析を目的として，さ らに遺伝子解析によるレース判別の可能性を探るため，イネ白 葉枯病菌各レースの代表菌株について RFLP 解析を行った。イ ネ白葉枯病菌由来の高頻度反復配列を含むpJEL101 をプロー ブとして, 各代表菌株の全 DNA を各種制限酵素で切断した断 片についてサザンブロット解析を行った結果，いずれの制限酵 素を用いても各代表菌株は固有の RFLP パターンを示し，相互 の重複は認められなかった。また，同じレースに属する日本産と インドネシア産菌株は互いに相同な場合と異なる場合とがみら れた。さらに，一部の品種に対する病原性の差異からレース IB およびIIIB に分類された菌株について検討した結果，それらは 各々レース IA および IIIA とは異なる RFLP パターンを示し た。しかしながら,同一レースに属する複数の菌株を供試して同 様な解析を行った場合，RFLP パターンによりさらに細分類が 可能であり，またレース I および II の一部の菌株間でパターン の重複が認められた。以上の結果から, pJEL101 をプローブと して RFLP パターンによる遺伝的多様性の解析，さらに各レー ス代表菌株の識別が可能であることが明らかとなった。しかし ながら，本法をレース判別に適用するためにはプローブの改良 あるいは新プローブの開発が必要であると考えられた。

(Received May 24, 1995; Accepted September 21, 1995) 